\title{
STRATEGI PENGEMBANGAN BUDAYA BERBASIS MADRASAH DAN PROBLEMATIKANYA (STUDI PADA MADRASAH ALIYAH NEGERI 3 PEKANBARU)
}

\author{
Rini Setyaningsih ${ }^{1}$, Fadilla Azrima ${ }^{2}$, Sesmita Maya Sari ${ }^{3}$ \\ ${ }^{123}$ Universitas Islam Negeri Sultan Syarif Kasim Riau \\ Email: rinisetyaningsih28@gmail.com
}

\begin{abstract}
ABSTRAK
Penelitian ini disusun untuk mengetahui strategi pengembangan budaya berbasis madrasah dan problematikanya di MAN 3 Pekanbaru. Metode yang dilakukan dalam penelitian ini yaitu deskriptif kualitatif dengan teknik pengumpulan data yaitu wawancara, observasi, dan dokumentasi. Dalam menganalisis data, penulis menggunakan reduksi data dan penyajian data, dan verifikasi data. Hasil penelitian menunjukkan bahwa pada dasarnya startegi pengembangan budaya madrasah itu memiliki nilai-nilai islami yang ditamankan pada diri peserta didik dan perlu didorong dengan prestasi akademik dan non akademik, Semua nilai-nilai tersebut perlu ditanankan pada semua kegiatan di dalam kelas maupun di luar kelas. Penulis melihat bahwa MAN 3 Pekanbaru telah menerapakan budaya unik yang tidak ada di madrasah lain seperti budaya panggilan Ayah dan Bunda untuk para tenaga pendidik, dan budaya tidak pacaran. Selain budaya yang unik tersebut, MAN 3 Pekanbaru juga menerapkan budaya disiplin, budaya sopan santun, saling menghargai dan menyayangi yakni seperti budaya yang telah ada di beberapa madrasah pada umumnya. Dalam pelaksanaan strategi pengembangan budaya di MAN 3 Pekanbaru, penulis masih menemukan beberapa kendala-kendala, namun Kepala Madrasah beserta stakeholders yang lain tetap melakukan pengawasan dan evaluasi berupa rapat internal, untuk terus meningkatkan kinerja dalam pengembangan budaya madrasah islami sehingga bisa menjadi lebih baik lagi.

Kata kunci: strategi, budaya, madrasah, problem
\end{abstract}

\begin{abstract}
This study was structured to determine the strategy for developing madrasah-based culture and its problems in MAN 3 Pekanbaru. The method used in this research is descriptive qualitative data collection techniques, namely interviews, observation, and documentation. In analyzing the data, the authors used data reduction and data presentation, and data verification. The results showed that basically the madrasah cultural development strategy has Islamic values that are secured in students and need to be encouraged by academic and non-academic achievements. All of these values need to be embedded in all activities in the classroom and outside the classroom. The author sees that MAN 3 Pekanbaru has applied a unique culture that does not exist in other madrasas such as the culture of calling Father and Mother for educators, and culture of not dating. In addition to a unique culture, MAN 3 Pekanbaru also implements a culture of discipline, a culture of courtesy, mutual respect and love, which is like the culture that has existed in several madrasas in general. In implementing the cultural development
\end{abstract}


strategy at MAN 3 Pekanbaru, the author still finds several obstacles, but the Head of Madrasah and other stakeholders will carry out supervision and evaluation in the form of internal meetings, to continue and improve performance in developing Islamic madrasah culture so that it can be even better.

Keywords: strategy, culture, madrasa, problem

\section{PENDAHULUAN}

Madrasah Aliyah merupakan salah satu model pendidikan islam hasil perpaduan antara pendidikan model sekolah dan pesantren. Dan tujuan pendidikan nasional adalah salah satunya mencerdaskan kehidupan bangsa. Sebagaimana yang terdapat dalam UU No 20 Tahun 2003 Tentang Sistem Pendidikan Nasional sudah ada kebijakan upaya peningkatan kualitas pendidikan di Indonesia, terutama mencerdaskan kehidupan bangsa. Oleh karena itu sekolah tidak hanya mengelola potensi dan kemampuan peserta didik sehingga menghasilkan peserta didik yang bermutu tetapi juga untuk menigkatkan nilai-nilai yang ada di sekolah. Selain itu, budaya juga suatu hal yang sangat penting dan mendukung tercapainya tujuan sekolah.

Budaya sekolah (madrasah) adalah karakteristik, kepribadian, atau ciri khas dari madrasah tersebut. Yang mana karakteristik kepribadian tersebut yang membedakannya dari sekolah atau madrasah lainnya.Budaya madrasah yang baik adalah budaya yang mendorong seluruh anggotal madrasah untuk terus meningkatkan mutu, kinerja dan potensinya agar tujuan madrasah dapat tercapai. Hal ini tidak terlepas dari peranan nilai-nilai moral, attitude dan perilaku siswa di sekolah.

Kehadiran undang-undang otonomi daerah telah membawa sejumlah perubahan, bukan hanya dalam bidang pemerintahan dan birokrasi, namun terutama dengan diserahkannya sejumlah kewenangan kepada daerah, salah satunya dalam bidang pendidikan. Kewenangan tersebut menuntut adanya perubahan berupa pembaruan sistem pendidikan yang sekian lama dikelola secara sentralistik oleh pemerintah pusat dengan menafikan keragaman, perbedaan, kultur, agama, dan sebagainya yang menyebabkan terpuruknya kualitas pendidikan di Indonesia. Banyak orang beranggapan bahwa pelaksanaan otonomi daerah memberikan harapan akan perbaikan penyelenggaraan pendidikan yang akan meningkatkan kualitas output-nya. Namun, ternyata harapan itu menghadapi berbagai tantangan. Salah satunya adalah pemegang kebijakan yang pola pikirnya masih sangat prosedural, serba juklak, juknis sehingga menghambat lahirnya kreativitas, motivasi, dan upaya-upaya inovatif. ${ }^{1}$

${ }^{1}$ Rini Setyaningsih and Siti Nikmatul Rochma, 'Internalisasi Nilai-Nilai Karakter Religius Siswa Di Madrasah Ibtidaiyah Nurussalam Mantingan', El-Ibtidaiy:Journal of Primary Education, 3.2 (2020), 83 <https://doi.org/10.24014/ejpe.v3i2.10590>. hal. 18 
Dalam manajemen pendidikan yang berbasis mutu/ kualitas ini lebih menekankan pada kemandirian dan kreativitas sekolah, sehingga dapat menghasilkan lulusan yang berkualitas. Dengan demikian, budaya di lingkungan madrasah itu sangat penting karena budaya madrasah merupakan karakteristik, kepribadian, ciri khas atau jati diri dari madrasah tersebut.

Beberapa hal yang menarik dari lokasi penelitian yaitu di MAN 3 Pekanbaru, terdapat beberapa struktur organisasi madrasah yang belum ada di madrsah pada umumnya. Struktur Madrasah yang dimaksud adalah adanya Wakil Kepala Madrasah bidang Keislaman (koordinator keislaman) dan staf keislaman. Tugas dan fungsi dari Waka Keislaman dan staf keislaman salah satunya adalah mempunyai peran atau tugas untuk menanamkan nilai-nilai islami guna mencapai budaya pendidikan yang berbaisis madrasah secara totalitas. Melalui hal tersebut dengan haparan seluruh siswa Madrasah yang ada di MAN 3 Pekanbaru mempunyai karakteristik islami dan akhlak al-karimah sesuai motto madrasah.

Oleh karena itu, penulis tertarik meneliti tentang startegi pengembangan budaya berbasis madrasah yang sangat erat hubunganya dengan manajemen berbasis madrasah di MAN 3 Kota Pekanbaru dengan memperhatikan penerapan nilai-nilai, dan kebiasaan-kebiasaan yang mendukung tercapainya tujuan madrasah yang diinginkan.

\section{METODE PENELITIAN}

Metode yang dilakukan dalam penelitian ini yaitu metode penelitian deskriptif kualitatif, dengan teknik pengumpulan data yaitu observasi, wawancara kepala madrasah, wakil kesiswaan sekaligus guru di MAN 3 Pekanbaru dan dokumentasi. Serta dalam analisis data, penulis menggunakan reduksi data dan penyajian data, dan verifikasi data. Lokasi penelitian yaitu di MAN 3 Kota Pekanbaru, objek dalam penelitian ini adalah strategi pengembangan budaya berbasis madrasah di MAN 3 Kota Pekanbaru.

\section{PEMBAHASAN}

\section{Manajemen Berbasis Madrasah}

Manajemen berbasis madrasah merupakan terjemahan dari school Based Management, istilah ini pertama kali muncul di Amerika Serikat ketika masyarakat mulai mempertanyakan relevansi pendidikan dengan tuntutan dan perkembangan zaman. ${ }^{2}$ Menurut UUD No 20 Tahun 2003 tentang Sistem Pendidikan Nasional, pasal 51 ayat 1, Manajemen berbasis madrasah adalah bentuk otonomi manajemen pendidikan pada satuan pendidikan, yang dalam hal ini kepala madrasah dan guru dibantu oleh komite madrasah dalam mengelola

\footnotetext{
${ }^{2}$ Ahmad Zaini Aziz, 'Manajemen Berbasis Sekolah: Alternatif Peningkatam Mutu $\begin{array}{lllll}\text { Pendidikan } & \text { Madrasah', } & \text { El-Tarbawi, } & 8.1 & \text { (2015), }\end{array}$ $<$ https://doi.org/10.20885/tarbawi.vol8.iss1.art5>.hal. 78
} 
kegiatan pendidikan. ${ }^{3}$ Menurut E. Mulyasa dalam Thesis Suparman, Manajemen Berbasis Madrasah (MBM) merupakan bentuk dari reformasi pendidikan yang memberikan penawaran kepada sekolah untuk menyediakan pendidikan yang lebih baik dan memadai bagi para peserta didik. ${ }^{4}$

Nanang Fatah menjelaskan bahwa manajemen berbasis madrasah adalah suatu upaya untuk mendesain ulang manajemen madrasah dengan menggunakan pendekatan politik (baik dari perencanaan, pengorganisasian, pernggerakan, dan pengawasan madrasah) yaitu dengan memberikan otoritas kepada kepala madrasah untuk meningkatkan kinerja dan partisipasi seluruh stakeholder dalam mencapai tujuan bersama. ${ }^{5}$

Jadi, manajemen berbasis madrasah merupakan sebuah strategi untuk memajukan pendidikan dengan mentransfer keputusan penting, memberikan otoritas dari Negara, dan pemerintah daerah kepada individu pelaksana di madrasah. Manajemen berbasis madrasah menyediakan kepala madrasah, guru, siswa, orang tua sebagai control yang sangat besar dalam proses pendidikan dengan memberikan mereka tanggung jawab untuk memutuskan anggaran, personil, serta kurikulum. Sehingga dapat difahami bahwa manajemen berbasis madrasah merupakan suatu pengelolaan terhadap lembaga pendidikan madrasah berdasarkan nilai-nilai Islami dan berpegang pada Al-Qur'an dan Sunnah dalam mencapai tujuan madrasah yang efektif dan efisien.

\section{Budaya berbasis Madrasah}

Secara etimologi budaya atau culture, dalam KBBI adalah "pikiran, akal budi, hasil."Sedangkan membudayakan adalah "mengajar supaya mempunyai budaya, mendidik supaya berbudaya, membiasakan sesuatu yang baik sehingga berbudaya." 6 Dalam bahasa sansekerta budaya berasal dari kata budh yang berarti akal, yang kemudian menjadi kata budhi atau budhaya sehingga kebudayaan diartikan sebagai hasil pemikiran atau akal manusia. Pendapat lain mengatakan bahwa budaya berasal dari kata budi dan daya. Budi adalah akal yang merupakan unsur rohani dalam kebudayaan sedangkan daya adalah perbuatan atau ikhtiar. ${ }^{7}$

${ }^{3} 20$ tahun 2003 UURI, 'Undang-Undang Nomor 20 Tahun 2003 Tentang Sistem Pendidikan Indonesia', Indonesia, 2003.

${ }^{4}$ Suparman, 'Manajemen Berbasis Madrasah (Studi Tentang Kepemimpinan Kepala Madrasah Tsanawiyah Negeri Model Palopo)' (Universitas Islam Negeri Alauddin Makasar, 2012).hal. 20

${ }^{5}$ Umul Aiman Lubis, 'Implementasi Manajement Berbasis Sekolah Dalam Meningkatkan Mutu Lulusan Di Sma Islam Al-Ulum Terpadu Medan', Analytica Islamica, 4.1 (2015), 16786.hal. 170

${ }^{6}$ Tim Pusat Bahasa Depdiknas, Pusat Bahasa Departemen Pendidikan Nasional, Kamus Bahasa Indonesia, 2008., hal. 226

${ }^{7}$ Supartono Widyosiswoyo, Ilmu Budya Dasar, (Bogor : Ghalia Indonesia, 2009) hal. 30- 
Secara terminologi budaya adalah suatu pola dalam perilaku, kesenian, kepercayaan dan seluruh karya dan hasil pemikiran manusia yang mencerminkan suatu kondisi dari masyarakat tertentu.Dan kebudayaan adalah adanya masyarakat yang berpegang pada hukum-hukum yang adil, dan memungkinkan kondisi ekonomi serta psikologis yang paling baik bagi warganya. ${ }^{8}$ Sedangkan menurut Koenjaraningrat dalam Jurnal Fuad Arif, kebudayaan secara terminologi adalah "keseluruhan sistem gagasan, tindakan dan hasil karya manusia dalam kehidupan masyarakat yang dijadikan milik diri manusia dengan belajar. ${ }^{9}$

Sebagai suatu organisasi atau lembaga pendidikan, madrasah juga memiliki ciri khas atau karakter tersendiri yaitu pembelajaran.Budaya dalam madrasah juga seharusnya menunjukkan wujud yang sesuai dengan prinsipprinsip kemanusiaan dan konsep budaya madrasah tentunya Islami dan berlandaskan Al-Qur'an dan Hadist. Yang mana konsep tersebut masuk kedalam pembelajaran sebagai upaya untuk meningkatkan mutu pendidikan dan memberikan arah terhadap efisiensi lingkungan pembelajaran.Jadi, budaya madrasah adalah segala kegiatan dan kebiasaan terdalam dalam lingkungan madrasah yang berlandaskan Islami, serta mampu meningkatkan mutu peserta didik pembelajaran lebih efektif dan efisien.

\section{Lingkungan Madrasah}

Lingkungan juga sangat berpengaruh dengan budaya, dimana lingkungan juga salah satu yang membentuk budaya yang ada. Lingkungan pendidikan meliputi situasi, kondisi dankeadaan yang berisikan suatu pembelajaran dan dengan cara-cara tertentu dapat mempengaruhi perilaku, pertumbuhandan perkembangan. Meskipun lingkungan juga tidak bertanggung jawab penuh terhadap proses kedewasaan peserta didik, tetapi lingkungan sangat berpengaruh terhadap tingkah lakunya. Lingkungan sekitar yangsengaja digunakan sebagai alat dalam proses pendidikan (seperti pakaian,keadaanruangan, buku-buku, alatperaga, sarana dan prasarana, dll)dinamakan lingkungan pendidikan. Lingkungan pendidikan dapat diartikan sebagai faktor yang berpengaruh terhadap pendidikan atau berbagai lingkungan tempat berlangsungan proses pendidikan. ${ }^{10}$

Lingkungan pendidikan yang ada di madrasah tentunya juga sebagai alat dalam proses pendidikan madrasah yang Islami dengan nilai-nilai yang lainnya. Yang mana lingkungan tersebut dapat mendorong peserta didik agar aktif berinteraksi dengan lingkungan sekitarnya sehingga dapat mencapai tujuan

\footnotetext{
${ }^{8}$ Nanang Fattah, Landasan Manajemen Pendidikan, Bandung: Remaja Rosdakarya, 2016, LIII.

${ }^{9}$ Fuad Arif Fudiyartanto, 'Penerjemahan Butir Budaya Dari Bahasa Inggris Ke Bahasa Indonesia', Adabiyyāt: Jurnal Bahasa Dan Sastra, $11.2 \quad$ (2012), 317 <https://doi.org/10.14421/ajbs.2012.11207>.hal. 321

${ }^{10}$ Nanang Fattah, Op. Cit., hal. 76
} 
pendidikan madrasah yang efektif dan efisien. Jadi, lingkungan madrasah adalah kondisi atau keadaan sekitar madrasah yang sangat memberikan pengaruh terhadap pembentukan sikap dan pengembangan potensi peserta didik, kinerja guru, dan seluruh stakeholder yang ada.

\section{Prinsip-prinsip Manajemen Budaya dan Lingkungan Sekolah/Madrasah}

Pengetahuan, kemanpuan, kinerja dan kesopanan para anggotamadrasah yang untuk memperoleh kepercayaan akan memberikan kesan yang meyakinkan bagi orang lain. Hal ini menuntut para guru, staf, dan kepala sekolah untuk professional, terampil, dan terlatih dalam menjalankan perannya.

Pengembangan budaya sebaiknya mengacu kepada beberapa prinsip berikut ini :

1. Berfokus pada Visi, Misi, dan Tujuan sekolah.

Pengembangan budaya madrasah harussejalan dengan visi, misi, dan tujuan sekolah. Hal ini mengarah pada pengembangan budaya madrasah.

2. Penciptaan komunikasi Formal dan Informal

Komunikasi adalah dasar bagi terciptanya koordinasi dan kerjasama yang baik dalam madrasah.Oleh karena itu penerapan komunikasi formal dan informal sangat penting, dan sebaiknya diberi pemisah agar lebih efektif dan efisien.Sehingga ada perbedaan antara kapan harus berkomunikasi formal dan informal.

3. Inovatif dan bersedia mengambil resiko

Budaya madrasahhendaknyamemiliki inovasi dan dan mampu mengambil resiko.Karena setiap inovasi terhadap budaya madrasahakan menimbulkan adanya resiko yang harus diterima.Hal inilah yang menyebabkan seorang pemimpin kurang berani mengambil sikap dan keputusan secara cepat.

4. Memiliki strategi yang jelas.

Budaya madrasahharus berlandaskan strategi dan program.Strategi yang mencakup langkah-langkah yang harus dilakukan dengan analisistertentu, dan program mencakup tentang kegiatan-kegiatan operasional yang perlu dilakukan yang mendukung jalannya stategi.

5. Berorientasi kinerja

Dalam pengembangan budaya madrasah perlu adanya arah pada sasaran yang terukur. Sasaran tersebut dapat diukur dan akan mempermudah pengukuran capaian kinerja dari suatu madrasah.

6. Sistem evaluasi yang jelas

Perlu dilakukan evaluasi rutin dan bertahap : jangka pendek, sedang, dan jangka panjang untuk mengetaui kinerja pengembangan budaya madrasah. Oleh karena itu perlu adanya sistem evaluasi yang jelas evaluasi apa yang akan dilakukan, kapan dilakukan, siapa yang melakukan, bagaimana melakukannya dan serta apa tindak lanjut yang harus dilakukan. 
7. Memiliki komitmen yang kuat

Budaya madrasa haruslah memiliki komitmen, komitmen dari seluruh stakeholdersangat menentukan jalannya program-program pengembangan budaya madrasah karena dengan adanya komitmen yang kuat dapat sebagai bukti akan terlaksananya program-program dengan baik..

8. Keputusan berdasarkan consensus

Budaya madrasah memiliki ciri positif apabila dalam pengambilan keputusan akan tertuju pada pengambilan keputusan secara consensus. Yang mana pengambilan keputusan secara consensus ini pada umumnya consensus dapat meningkatkan komitmen para stakeholder.

9. Sistem imbalan yang jelas

Budaya sekolah hendaknnya memiliki sistem imbalan yang jelas, apakah dalam bentuk barang, uang, pernghargaan, poin dan lain sebagainya yang bernilai guna sebagai imbalan.

10. Evaluasi diri

Salah satu alat untuk menilai dan mengetahui masalah-masalah yang dihadapi di madrasah yaitu dengan evaluasi diri.Selain untuk mengetahui masalah-masalah atau kekurangan dalam penerapan budaya madrasah maka evaluasi dapat dilakukan agar mengetahui alasan dan langkah yang harus dilakukan selanjutnya dalam pengembangan budaya madrasah. ${ }^{11}$

\section{Iklim Madrasah}

Mulyasa dalam Astuti menjelasakan bahwa Iklim dan budaya Madrasah yang kondusif ditandai dengan terciptanya lingkungan belajara yang aman, nyaman, dan tertib, sehingga pembelajaran dapat berlangsung secara efektif. Iklim dan budaya Madrasah yang kondusif sangat penting agar peserta didik merasa senang, dan bersikap positif teradap sekolahnya, agar guru merasa dihargai, serta agar orang tua dan masayarakat merasa diterima dan dilibatkan. Iklim Madrasah dapat tercipta dengan adanya penciptaan norma dan kebiasaan yang positif serta hubungan kerjasama yang terjali harmonis dengan mendasari rasa saling menghargai dan menghormati.selain itu iklim Madrasah yang konduif mendorong semua warga madrasah untuk sama-sama mencapai tujuan Madrasah. ${ }^{12}$

\footnotetext{
${ }^{11}$ Dewi Sri Utami, 'Strategi Peningkatan Mutu Pendidikan Melalui Budaya Sekolah Di SMPN 1 Prambon Kabupaten Nganjuk', Jurnal Pendidikan Dan Studi Keislaman, 8.1 (2018). hal. $46-47$

12 Astuti, 'Pengembangan Budaya Dan Iklim Sekolah', Adaara: Jurnal Manajemen Pendidikan Islam, 6.1 (2018), 467-83 <https://doi.org/10.35673/ajmpi.v6i1.267>. hal. 469
} 
Dalam penciptaan iklim Madrasah, ada beberapa hal yang menjadi karakteristik Iklim Madrasah diantaranya yaitu:

a) Kesesuaian, kesesuaian erat kaitannya dengan emosional berupa perasaan yang ada yang tertuju pada tuntutan dari luar Madrasah, sudut pandang yang bertolak pada banyaknya aturan, norma dan kebijakan dan tanggung jawab.

b) Taggung jawab, berkaitan erat dengan adanya pemberian tanggung jawab dari Madrasah kepada semua personil untuk mencapai tujuan Madrasah. Dengan adanya tanggung jawab yang dilaksanakan dengan baik maka madrasah bisa mencari personil sekolah yang profesional yang dapat dijadikan bahan pembuat keputusan dalam mencari solusi untuk mengatasi permasalahan yang dihadapi Madrasah.

c) Standart, yaitu berupa ambang batas untuk mengukur pencapaian tujuan Madrasah yang terdiri dari mutu atau kualitas dan pencapaian suau hasil dan prestasi yang dapat meningkatkan kualitas Madrasah di lingkungannya.

d) Penghargaan, adanya rasa diberikan apresiasi dari pihak Madrasah bisa dengan Reward bagi warga Madrasah yang bertanggung jawab dan profesional dan hukuman berupa teguran dan krtikan yang bersifat membangun yang berdamapak pada kemajuan Madrasah.

e) Kejelasan struktur madrasah, berupa adanya pembagian tugas kerja dan kejelasan informasi mengenai tugas pokok dan fungsi pada struktur Madrasah agar tidak terjadi kesalahpahaman pada saat bekerja dan dengan adanya kejelasan Struktur akan berpengaruh juga pada proses kerja agar mencapai tujuan yang efektif dan efeisien.

f) Kehangatan dan dukungan, adanya rasa empati dan saling berkoordinasi untuk menciptakan keharmonisan dan kepercayaan dalam lingkungan Madrasah

g) Kepemimpinan, kepemimpinan yang baik yang diterapkan oleh kepala Madrasah akan berpengaruh pada guru,staf dan siswa untuk menerima setiap arahan dan bentuk bimbingan dari pimpinan Madrasah.

Menurut Silver dalam M.M Wahyuninggrum H, berkaitan dengan karakteristik di atas maka untuk menciptakan Iklim Madrasah ada beberapa faktor yang mempengaruhi iklim Madrasah yang menyebutkan bahwa perilaku kepala sekolah/Madrasah yang dapat mempengaruhi pengelolaan iklim madrasah, yaitu ada empat hal meliputi: ${ }^{13}$

${ }^{13}$ MM Wahyuningrum, 'Peranan Kepala Sekolah Dalam Menciptakan Iklim Sekolah Di Era Otonomi Sekolah (Suatu Kajian Manajerial)', Jurnal Manajemen Pendidikan, 4.2 (2008), 6278.. hal.. 71-72 
1. Menciptakan jarak hubungan atau perilaku

2. Menekankan produksi ekolah/madrasah

3. Membuat persahabatan atau menjalin persaudaraan

4. Mempertimbangkan kemanusiaan atau individualitas

\section{Asas-Asas Pengembangan Budaya Madrasah}

Dalam pengembangan budaya Madrasah, ada asas atau yang menjadi patokan dasar dalam mengembangakan budaya Madrasah. Mengacu pada pendapat Astuti maka penulis dapat menjabarkan beberapa asas yang perlu dimiliki oleh Madrasah yang meliputi: ${ }^{14}$

1. Kerjasama tim (team work).

Kerja sama yang terjalin dalam organisasi Madrasah akan berpengaruh besar terhadap pencapaian tujuan utama Madrasah. Kerja sama tim adalah hal yang paling berpotensi bagi terciptanya pembangunan sumber daya manusia dan pembagunan keunggulan dan kekuatan yang harus ditonjolkan Madrasah. Oleh karena itu kerja sama tim dibangun atas semua aktivitas individu yang terkumpul dalam organisasi Madrasah yang memiliki persamaan tujuan untuk pencapaian tujuan Madrasah.

2. Kemampuan

Merujuk pada kesanggupan pihak pengemban tugas untuk melaksanakan tugas dan tanggung jawabnya baik itu pada tingkat kelas ataupun tingkat Madrasah. Bentuk kemampuan guru dalam bekerja adalah kemapuan guru dalam mengusasi semua kompetensinya dan begitu juga dengan kemampuan pemimpinnya yaitu kemampuan kepala sekolah dalam memainkan perannya sebagai pemimpin, manajer, evaluator, supervisor, fasilitastor, dan peran lainnya yang dapat memberikan pengaruhnya terhadap kemajuan Madrasah.

3. Keinginan

Keinginan berarti kemauan dan kesungguhan seseorang dalam menjalankan tugas dan tanggung jawabnya untuk mencapai kepuasan dalambekerja dengan sepenuh hati. Keinginan Madrasah tergantung pada keinginan semua warga sekolah dalam mendapatkan kepuasan dari konsumen pendidikan. Keinginan yang diarahkan untuk mencapai tujuan Madrasah dengan semua kemampuan dan kompetensi yang ada untuk melaksanakan tugas dan tanggung jawab yang menjadi budaya kerja di Madrasah.

4. Kegembiraan (happiness)

Kegembiraan adalah suatu hal yang harus tertanam di jiwa individu Madrasah dengan kata lain apabila semua personil madrasah

\footnotetext{
${ }^{14}$ Astuti, Op. Cit.. hal. 478-481
} 
mengedepankan kegembiraan pada setiap tindakannya dharapkan dapat memberikan implementasi dan umpan balik pada lingkungan dan iklim Madrasah. Kegembiraan yang dirasakan oleh semua personil madrasah bisa berupa adanya pengembangan budaya keramahan, kenyamanan dan kesopanan di madrasah. Contohnya sekolah dengan asas kegembiraan akan berupaya memberikan hal yang meningkatkan kegembiraan semua warga madrasah seperti budaya kedisiplinann patuh terhadap atauarn dan norma yang dilaksanakan berdasarkan rasa gembira.

5. Hormat (respect)

Asas hormat menghormati menjadi dasar terciptanya nilai yang memberikan apresiasi atau penghargaan terhadap semua personil di lingkungan Madrasah. Rasa hormat di lingkungan Madrasah bisa ditandai dengan adanya budaya saling menghargai, menghormati dan menerima dengan lapang dada dan hati yang ihklas, dan kehadiran senyuman di setiap sapaan akan menunjukkan rasa hormat yang tinggi di lingkungan Madrasah. Apabila sikap hormat ditanamkan dan membudaya di jiwa semua warga Madrasah maka akan mendapatkan citra baik bagi perkembangan Madrasah di masyarakat. Madrasah akan diprcaya oleh masyarakat dengan kepercayaan yang tinggi dan rasa tenang dengan pelayanan dan rasa hormat menghormati yang tertanamkuat.

6. Jujur (honesty)

Nilai kejujuran menjadi dasar etika penentu profil Madrasah, oleh karena itu sikap jujur menjadi pedoman untuk mengetahui pelayanan sekolah. kejujuran bisa berpengaruh pada tingkat kepercayaan seseorang kepada kita, baik itu kejujuran pada diri sendiri dan pada orang lain akan sangat berimbas pada perhargaan terhadap diri sendiri dan orang lain. Kejujuran di lingkungan Madrasah atau masayarakat harus sennatiasa dijadikan kebiasaan yang membudaya dalam setiap situasi dan kondisi, dalam lingkungan sekoilah bisa berupa sifat jujur dalam hal pengelolaan keuangan, aset dan lainnya dan kejujuran erat kaitannya dnegan keterbukaan padasetiap elemen di sekiolah. Kejujuran mencerminkan diri secara langsung oleh karena itu untuk mendapatakan diri yang beretika perbaikilah kejujuran maka akan terciptalah kepercayaan dan kesesuaian anatara perkataan dan tindakan di lapangan.

7. Disiplin (discipline).

Disiplin dapat diartikan sebagai suatu bentuk tindakan yang mencerminkan kepatuhan terhadap aturan dan norma yang berlaku di madrasah. Asas disiplin yang dimaksud adalah perilaku disiplin tercipta dari kesadaran penuh dan rela melaksanakan aturan itu dengan penuh tanggung jawab untuk menjalani kehidupan yang teratur, tertata dan 
sistematis yang dapat menempatkan sesuatu sesuai tempat dan situasi serta kondisinya. Jadi, disiplin itu muncul dari diri sendiri dan mengalir di jiwa personil madrasah yang ingin dan memiliki keadaran untuk melaksanakan semua aturan yang ada baik itu dilingkungan madrasha atau di lingkungan masyarakat untuk itu perlu diciptakan budaya yang mengarahkan pada kedisiplinan.

8. Empati (empathy)

Empati merupakan suatu bentuk perasaan dan sikap yang ditunjukkan untuk bisa berupaya menrasakan juga apa yang dirasakan oleh orang lain dengan adanya dorongan dari diri sendiri dan oranga lain. sikap empati harus dimiliki oleh semua personil sekolah agar dalam berinteraksi dan berkomunikasi dengan semua orang dimanapun dan kapanpun bisa menguasi perasaan orang lain itu dan ikut merasakan apa yang sedang dirasakan, bisa dengan memberikan bantuan berupa solusi terhadap permasalahan yang terjadi dengan saran, dan bisa berupa dukungan moral dan materil. Dengan adanya sikap empati di lingkungan Madrasah maka semua waraga atau personil akan bisa saling menhargai dan memahami satu sama lain, maka akan terciptalah budaya sekolah atau madrasah yang menjunjung tinggi rasa saling memahami atau empati.

9. Pengetahuan dan Kesopanan

Pengetahuan dan kesopanan yang dimiliki oleh semua warga sekolah atau madrasah yang diikuti dengan kemampun atau keterampilan untuk mendapatkan kepercayaan dari pihak lain tentang pengetahuan yang dimiliki akan memberikan sebuah kesan dan umpan balik bagi apa yang disampaikan akan dapat dimengerti orang lain dengan pengetahuan yang baik dan kesopanan yang baik juga.Asas pengetahuan dan kesopanan ini mengharuskan setiap personil madrasah yaitu kepala madrasah, pendidik,dan tenaga kependidikan untuk bisa mengimplementaikan pengetahuan dan menyeimbangi dengan kesopanan para personil sekolah yang disertai dengan kemampuan untuk memperoleh pencapaian kompetensi dan pelaksanaan peran masing-masing personil di madrasah. Dimensi ini menuntut para guru, staf dan kepala sekolah tarmpil, profesional dan terlatih dalam memainkan perannya memenuhi tuntutan dan kebutuhan siswa, orang tua dan masyarakat. 


\section{HASIL PENELITIAN}

Berdasarkan hasil wawancara, observasi dan dokumentasi, penulis mendapatkan informasi tentang strategi pengembangan budaya berbasis madrasah dan problematikanya yang diterapkan di MAN 3 Kota Pekanbaru.

\section{Budaya dilingkungan MAN 3 Kota Pekanbaru}

Budaya madrasah dibangun atas norma yang berkembang, artifak, dan lingkungan belajar, penegakan aturan filosofi madrasah dan nilai nilai dominan yaitu nilai-nila islami. Untuk menigkatkan budaya madrasah maka kepala madrasah perlu melestarikan budaya. Budaya yang ada di MAN 3 Kota Pekanbaru ini berupa nilai nilai islami, nilai aqidah, akhlakul karimah, disiplin, sopan santun, saling menghargai dan menghormati baik kepada guru maupu semua yang lebih tua darinya, berwawasan global, unggul, serta memiliki kreativitas, inovatif, serta berpikir kritis. Yang mana juga tercantum dalam visi, misi, dan moto madrasah.

Dari visi, misi, dan motto tersebut, sudah menggambarkan budaya yang ada di MAN 3 Kota Pekanbaru ini, dimana kepala madrasah guru dan Stakeholder membantu dalam mengembangkan mutu pendidikan dengan menerapkan dan mengembangkan budaya madrasah yang meliputi nilai-nilai islami, berwawasan global, memiliki keunggulan dalam bidang akadmik dan riset, serta peka terhadap lingkungannya. Dan sesuai dengan Motto GEMILANG tersebut, yaitu Giat, Edukatif, Motivatif, Inovatif, Luwes, Agamis, Nyaman, dan Gemar.

Dari hasil observasi yang dilakukan penulis menggambarkan bahwa budaya madrasah di MAN 3 Kota Pekanbaru ini sesuai dengan visi, misi, dan motto yang lebih menekankan pada aspek nilai nilai Islami. Dan yang menjadi ciri khas yaitu adanya suatu panggilan khusus kepada guru yang tidak ada di madrasah lain dan sudah menjadi budaya yaitu ayah dan bunda. Selain panggilan ayah bunda ada budaya lain yang diterapakan yaitu seperti Shalat berjamaah, baik Shalat Dhuha, Shalat Dzuhur, dan Shalat Ashar. Serta adanya budaya mengahafal Al-Qur'an. Selain itu, pihak sekolah juga menjaga dan sangat memperhatikan masalah pacaran yang sangat sering terjadi saat ini khususnya untuk remaja, dan MAN 3 Kota Pekanbaru ini menjaga ketat dan mengawasi peserta didik mereka agar tidak berpacaran dan terjerumus dalam hal-hal negatif yang dapat merusak konsentrasi belajar ataupun prestasi. Hal ini menjadi peraturan dan menjadi kebiasaan di madrasah ini agar norma dan nilai agama dan moralitas tetap membudaya dilingkungan madrasah dan dapat berkembang di lingkungan masyarakat.

Jadi, selain budaya di atas ada budaya lain yang diterapkan yaitu budaya senyum, sapa, salam, budaya shalat berjama'ah, tidak mencontek dalam ujian, budaya-budaya ini merupakan bentuk pengembangan budaya dalam kegiatan intrakulikuler nya. Dimana budaya-budaya tersebut berfungsi untuk membentuk karakter yang dimiliki peserta didik agar tidak hanya di berlaku di sekolah/ 
madrasah saja, tertapi juga masih tetanam saat mereka lulus dari sekolah tersebut. Karna point penting dari penanaman pengembangan budaya adalah bagaimana peserta didik dapat terus berpegang pada apa yang sudah diajarkan oleh guru-guru disekolah dan mengimplementasikannya dalam kehidupan bermasyarakat. Dengan kata lain, penciptaan dan pengembangan budaya madrasah yang demikian diarahkan agar semua warga sekolah dapat mampu diterima dalam masyarakat.

\section{Pengembangan budaya dalam kegiatan ektrakulikuler}

Selain pengembangan budaya dalam kegiatan ektrakurikuler, pengembangan budaya dalam kegiatan kelas juga penting, bagaimana pendidik harus mampu mengembangkan budaya dan potensi peserta didik dalam proses belajar mengajar didalam kelas, seperti yang sudah dijelaskan sebelumnya di MAN 3 Kota Pekanbaru ini memiliki budaya dengan nilai-nilai Islami, dan kegiatan intrakulikulernya seperti yang disebutkan di atas berupa senyum sapa salam, Tahfiz 15-20 menit sebelum pembelajaran, shalat berjama'ah, sopan santun, disiplin, budaya tidak mencontek dan lain sebagainya yang mendukung terbentuknya budaya. Karna pada dasarnya budaya itu di paksakan sebagai bentuk aturan yang harus diikuti baik sebagai warga madrasah maupun lulusan alumni.

Untuk kegiatan ekstrakulikulernya MAN 3 Pekanbaru lebih memfokuskan kecintaan pada Seni dan Olahraga, Pramuka, Rohis, PMR, Sanggar Sastra, Bina Musik dan Marawis. Dengan pengembangan budaya inilah pendidik dapat menanamkan nilai-nilai kedisiplinan, kepemimpinan,kerjasama tim, memiliki tanggung jawab, sopan santun, kebersamaan, dan kecintaan terhadap lingkungan. Jadi, dari segi strategi pengembangan budaya dalam kegiatan intrakurikuler dan ekstrakurikuler MAN 3 Kota Pekanbaru ini telah melaksanakannya dengan baik, baik dari segi akademik maupun nonakademiknya. Hal ini tentu dapat mendorong terwujudnya visi dan misi madrasah dan mencapai tujuan serta unggul dan mampu bersaing dengan sekolah/madrasah lainnya.

\section{Dampak budaya terhadap lingkungan Madrasah}

Dampak budaya terhadap lingkungan MAN 3 Kota Pekanbaru ini banyak berupa prestasi akademik dan nonakademik serta nilai-nilai yang ditanamkan atau diajarkan melekat pada diri peserta didik tersebut. Kebiasaan dan nilai-nilai yang berikan kepada peserta didik diharapkan dapat tertanam dan menjadi pegangan mereka ditengah masyarakat.

Pada dasarnya budaya dan kebijakan yang diambil oleh kepala madrasah itu sifatnya memaksa, dalam arti kata perlu adanya pembiasaan. Jika suatu hal contohnya budaya disiplin jika diterapkan dan dibiasakan maka akan menjadi budaya disiplin yang kuat. Demikian juga dengan budaya-budaya yang lainnya seperti budaya tidak pacaran,tidak mencontek saat ujian, selalau membudayakan senyum,salam dan sapa. Dengan pembiasaan dan paksaan yang demikian 
pelaksaanaan aturan tersebut akhirnya menjadi budaya tersendiri di madraah. Jadi dalam lingkungan madrasah dampak adanya budaya di madrasah sangat berpengaruh pada pencapaian prestasi siswa dan eksistensi madrasah di dalam masyarakat.

\section{Problematika yang dihadapi dalam mengembangkan budaya madrasah}

Problematika atau masalah yang dihadapi dalam mengembangkan budaya tentu ada, baik dari internal maupun eksternal. Pada tahapan penciptaan dan pengembangan budaya di madrasah adanya ketidak efektifan dalam pelaksanaanya maka hal itu juga menjadi problematikanya. Seperti telah diterapkannya budaya disiplin, akan tetapi masih ada peserta didik yang tidak disiplin, atau penerapan budaya islami terutama budaya tidak pacaran yang mana masih dalam pengawasan dan guru serta stakeholder juga harus bekerja sama dalam mengawasi peserta didik. Karna masih ditemukan peserta didik yang berpacaran. Dan juga banyak alasan-alasan lain yang dilakukan peserta didik yang tidak sesuai dengan budayanya. Dengan ketidakesuaian aturan dengan peklaksana aturan tersebut maka terjadilah tumpang tindih dalam mengembnagkan budaya madrasah. Hal-hal sepert inilah yang menjadi tugas kepala madrasah dan seluruh stakeholder untuk bisa lebih fokus menerapkan budaya tersebut sehingga budaya tersebut dapat lebih kuat.

Sehingga apabila terjadi ketidaksepakatan antara pengembangan budaya tersebut maka dapat dilakukan pemecahan masalah dengan evaluasi. Oleh karena itu, perlu ada evaluasi untuk melihat proses pengembangan budaya yang harus diperbaiki, agar tidak terjadi lagi hal-hal demikian. Dan dalam observasi yang dilakukan diketahui bahwa solusi dari masalah dalam pengembangan budaya madrasah yaitu kepala madrasah selalu melakukan evaluasi dan pengawasan, yang dibantu oleh stakeholder. Evaluasi ini terkait aturan yang telah diterapkan di madrasah setelah berjalan dan dilaksanakan maka kepala madrasah memantau apakah ada perubahan yang signifikan terhadap perkembangan nilai-nilai yang ada dan norma di masyarakat kemudian dilakukan perbaikan untuk memodifikasi aturan yang ada dan disesuaikan dengan tujuan madrasah agar setiap aturan yang diterapkan bisa menjadi suatu yang tidak memberatkan dan menjadi kebiasaan dan pada akhirnya menjadi budaya madrasah yang mengakar kuat dilingkungan madrasah.

\section{Evaluasi dan solusi dalam pengembangan budaya madrasah}

Kepala madrasah memiliki pengaruh posotif budaya, yang mana kebijakan dan regulasi ditetapkan oleh pemimpin. Dan kepala madrasah juga sangat berperan penting dalam pengembangan budaya madrasah. Budaya madrasah dibangun atas norma yang berkembang, artifak, dan lingkungan belajar, penegakan aturan filosofi madrasah dan nilai-nilai dominan yaitu nilai-nilai 
islami. Untuk menigkatkan budaya madrasah maka kepala madrasah perlu melestarikan budaya. Dan tidak hanya peran kepala madrasah semata semua warga madrasah harus berupaya melestarikan budaya yang menjadi bagian dari madrasah.

Dalam hal ini guru juga melibatkan peserta didik berkerja sama dengan waka humas dalam mengawasi jalannya budaya seperti budaya shalat berjama'ah. Guru meminta kepengurusan Rohis sekolah dalam memeriksa peserta didik untuk dapat tertib. Selain itu guru juga mendapatkan dukungan, kerjasama, solusi dan informasi dari alumni sekolah sehingga pengembangan budaya di Madrasah ini dapat terus berkembang menjadi lebih baik lagi.

\section{KESIMPULAN}

Dari hasil wawancara dan observasi yang telah dilakukan di MAN 3 Kota Pekanbaru, diketahui bahwa pada dasarnya budaya madrasah itu memiliki nilai nilai islami yang ditamankan pada diri peserta didik dan didorong juga dengan prestasi akademik dan non akademik, baik di dalam kelas maupun kegiatan di luar kelas. Dan MAN 3 Kota Pekanbaru telah menerapkan budaya yang tidak ada dimadrasah lain seperti budaya panggilan Ayah Bunda, dan budaya tidak pacaran, Kepala Madrasah MAN 3 Pekanbaru juga menanamkan budaya disiplin, budaya sopan santun, saling menghargai dan menyayangi. Dan meskipun dalam penerapan budaya tersebut masih ada terjadi kendala kendala, namun kepala madrasah akan melakukan pengawasan dan evaluasi berupa rapat internal, untuk pengembangan budaya madrasah sehingga menjadi lebih baik lagi.

\section{DAFTAR PUSTAKA}

Astuti, 'Pengembangan Budaya Dan Iklim Sekolah', Adaara: Jurnal Manajemen $\begin{array}{llll}\text { Pendidikan } & \text { Islam, } & 6.1 & \text { (2018), }\end{array}$ $<$ https://doi.org/10.35673/ajmpi.v6i1.267>.

Aziz, Ahmad Zaini, 'Manajemen Berbasis Sekolah: Alternatif Peningkatam Mutu Pendidikan Madrasah', El-Tarbawi, 8.1 (2015), 69-92 <https://doi.org/10.20885/tarbawi.vol8.iss1.art5>.

Depdiknas, Tim Pusat Bahasa, Pusat Bahasa Departemen Pendidikan Nasional, Kamus Bahasa Indonesia, 2008.

Fattah, Nanang, Landasan Manajemen Pendidikan, Bandung: Remaja Rosdakarya, 2016, LIII.

Fudiyartanto, Fuad Arif, 'Penerjemahan Butir Budaya Dari Bahasa Inggris Ke Bahasa Indonesia', Adabiyyāt: Jurnal Bahasa Dan Sastra, 11.2 (2012), 317 <https://doi.org/10.14421/ajbs.2012.11207>.

Lubis, Umul Aiman, 'Implementasi Manajement Berbasis Sekolah Dalam Meningkatkan Mutu Lulusan Di Sma Islam Al-Ulum Terpadu Medan', Analytica Islamica, 4.1 (2015), 167-86.

Setyaningsih, Rini, and Siti Nikmatul Rochma, 'Internalisasi Nilai-Nilai Karakter Religius Siswa Di Madrasah Ibtidaiyah Nurussalam Mantingan', El- 
Ibtidaiy:Journal of Primary Education, $3.2 \quad$ (2020), 83 <https://doi.org/10.24014/ejpe.v3i2.10590>.

Sri Utami, Dewi, 'Strategi Peningkatan Mutu Pendidikan Melalui Budaya Sekolah Di SMPN 1 Prambon Kabupaten Nganjuk', Jurnal Pendidikan Dan Studi Keislaman, 8.1 (2018).

Suparman, 'Manajemen Berbasis Madrasah (Studi Tentang Kepemimpinan Kepala Madrasah Tsanawiyah Negeri Model Palopo)' (Universitas Islam Negeri Alauddin Makasar, 2012).

UURI, 20 tahun 2003, 'Undang-Undang Nomor 20 Tahun 2003 Tentang Sistem Pendidikan Indonesia', Indonesia, 2003

Wahyuningrum, MM, 'Peranan Kepala Sekolah Dalam Menciptakan Iklim Sekolah Di Era Otonomi Sekolah (Suatu Kajian Manajerial)', Jurnal Manajemen Pendidikan, 4.2 (2008), 62-78

Widyosiswoyo, Supartono. Ilmu Budya Dasar, (Bogor : Ghalia Indonesia, 2009). 